\title{
The efficiency of Corynebacterium cutis lysate in cows with subclinical mastitis
}

\author{
Nevzat Saat ${ }^{1}$, Murat Yuksel$^{2}$, Zulal Asci Toraman ${ }^{3}$ and Ali Risvanli ${ }^{4^{*}}$
}

${ }^{1}$ Department of Obstetrics and Gynecology, Faculty of Veterinary Medicine, University of Balikesir, Balikesir, Turkey; ${ }^{2}$ Department of Obstetrics and Gynecology, Faculty of Veterinary Medicine, University of Cumhuriyet, Sivas, Turkey; ${ }^{3}$ Department of Microbiology, Faculty of Medicine, University of Firat, Elazig, Turkey; ${ }^{4}$ Department of Obstetrics and Gynecology, Faculty of Veterinary Medicine, University of Firat, Elazig, Turkey

\section{Article history}

Received: 20 Apr, 2016

Revised: 2 May, 2016

Accepted: 3 May, 2016

\section{Abstract}

In this study, it was aimed to determine the therapeutic efficiency of Corynebacterium cutis lysate that is a nonspecific immunostimulant in cows with subclinical mastitis. The study material was 88 udder lobs with subclinical mastitis of cows from different breeds and age (4-7 years) based on the same farm. Subclinical mastitis was diagnosed by microbiological tests, California Mastitis Test (CMT) and Somatic Cell Count (SCC). $10 \mathrm{ml}$ of Corynebacterium cutis lysate was injected subcutaneously to the animals which were diagnosed with subclinical mastitis. After 15 days from the injection microbiological tests, CMT and SCC determinations were performed in the same udder lobs. Additionally, milk samples were taken from the said udder lobs before and after Enzyme-Linked Immunosorbent Assay (ELISA) determined immunoglobulin $\mathrm{G}(\mathrm{IgG})$ concentrations. CMT positivity rates, SCC and IgG levels before and after Corynebacterium cutis lysate injections were $100 \%$ and $63.63 \%$; 897.470 and $923.780 \mathrm{cell} / \mathrm{ml} ; 845.11$ and $887.27 \mathrm{mg} / \mathrm{ml}$, respectively. The microbiological growth rates before and after the applications were found to be $13.63 \%$ and $22.73 \%$, respectively. The obtained data showed that, although not statistically significant, microbiological growth rates and SCC were increased after Corynebacterium cutis lysate application to the cows with subclinical mastitis. However, it was observed that the milk $\operatorname{IgG}$ levels were increased significantly after the application. These results may indicate the use of Corynebacterium cutis lysate applications as a supportive treatment to enhance the resistance in cows against subclinical mastitis.
\end{abstract}

Keywords: Corynebacterium cutis; subclinical mastitis; therapy; cow

\footnotetext{
To cite this article: Saat N, M Yuksel, ZA Toraman and A Risvanli, 2016. The efficiency of Corynebacterium cutis lysate in cows with subclinical mastitis. Res. Opin. Anim. Vet. Sci., 6(3): 108-110.
}

\section{Introduction}

There are many predisposition factors in the forming of subclinical mastitis such as the anatomy of the udder, breed sensitivity, lack of hygiene, and inappropriate milking (Koc, 2008; Gurbulak et al., 2009; Seker et al., 2009; Bastan, 2013). The immune situation of the animal also plays an important role in these factors. In this regard, having the immune situation of the animals in a high level decreases the

*Corresponding author: Ali Risvanli, Department of Obstetrics and Gynecology, Faculty of Veterinary Medicine, University of Firat, Elazig, Turkey; E-mail: arisvanli@firat.edu.tr; Phone: +90 42423700 00/6169; Fax: + 904242388173 
prevalence of the infection. Keeping the animals away from stress, to make ration supplements or application of different immunostimulant agents are the methods which are used improve the immune system of the animals (Lee et al., 1996; Gurbulak and Kilicarslan, 2004; Pretorius, 2008). Corynebacterium cutis lysate is one of these immunostimulants and is frequently used for the preservation and the treatment of various diseases, recently but there is not much information with respect to its use in cows with subclinical mastitis (Senturk et al., 2003; Gurbulak and Kilicarslan, 2004).

Corynebacterium cutis lysate stimulates the phagocytic activity (Al-Izzi et al., 1982). Dead Corynebacterium cutis bacteria are easily phagocytized by the macrophages when administered to the organism and then stimulates the release of TNF, IL-1 and IL-6 from the macrophages (Shalaby et al., 1992). These cytokines generates a secondary effect on lymphocyte function and provides the release of IL-2 and IFN- $\gamma$, therefore the reactivation of the immune system (Conesa et al., 2005).

In this study, it is aimed to find the therapeutic efficiency of Corynebacterium cutis lysate, which is a nonspecific immunostimulant, based on its impact on the CMT, SCC, IgG levels and microbiological growth rates in the milk of the cows with subclinical mastitis.

\section{Materials and Methods}

In this study, 88 udder lobs with subclinical mastitis belonging to 30 Simmental cows (age $=4-7$ years), which were selected from 500 cows in Elazig, were used. The cows were milked twice a day and their average lactation milk yields were 5500 liters. Cows were housed in sandgrounded, semi-open, freely circulated barns during the year. There were concentrated food, barley, dry grass, corn silage, clover and straw in the ration.

This research was evaluated by Firat University Animal Experiments Ethics Committee and was found to be appropriate with the decision number 2013/13 and 135 .

$10 \mathrm{ml}(200 \mathrm{mg})$ of Corynebacterium cutis lysate (Ultra-corn Virbac, France) were injected subcutaneously to the animals, which were evaluated as CMT positive. Milk samples were taken in $5 \mathrm{ml}$ plastic tubes for Somatic Cell Count (SCC), $10 \mathrm{ml}$ sterile glass tubes for microbiological analysis, and $2 \mathrm{ml}$ for immunological analysis before and 15 days after the injection from the California Mastitis Test (CMT) positive udder lobs. The first application was performed control group for the study.

Microbiological analyses were performed by culturing to 5\% blood agar and MacConkey agar at aerobic, anaerobic and microaerophilic conditions incubated at $38^{\circ} \mathrm{C}$ (Koneman et al., 1997). Samples in eppendorf tubes were kept at $-20^{\circ} \mathrm{C}$ until further analyses. Somatic cell counts were made by DeLaval Cell
Counter® (DeLaval International, Sweden) cell counter device (Smith, 1996). IgG measurements were performed using a commercial Bovine IgG ELISA Test package (Cusabio Biotech Co., Ltd.) and an ELISA reader (Biotek ELX800) (Conesa et al., 2005).

\section{Statistical analysis}

The data before and after Corynebacterium cutis injection were statistically analyzed using paired sample t-test and Pearson correlation test. In addition, the relation between microbiologically grown and non-grown udder lobs was determined using Mc Nemar Chi Square Test.

\section{Results and Discussion}

The udder lobs that were all CMT positive before the injection were evaluated $63.63 \%(\mathrm{n}=56)$ as positive (Table 1).

Total $\mathrm{IgG}$ levels in milk were determined to be $845.11 \pm 8.09$ and $887.27 \pm 9.07 \mathrm{mg} / \mathrm{ml}$ before and after the injection, respectively (Table 1). This increase in the total IgG levels was found to be statistically significant $(\mathrm{P}<0.05)$.

Microbiological proliferation was observed in the $13.63 \%$ of the samples taken before the injection and in the $22.73 \%$ of the samples taken after the injection. Taking into consideration the microbiological growth rates, no statistically significant difference was found ( $>0.05)$ (Table 1).

Many researchers investigated nonspecific immunostimulant use of Corynebacterium species against bacterial, viral and protozoal diseases, previously (Lee et al., 1996; Pyorala, 2003). In a study, 99 Holstein cows which were identified having high somatic cell counts in their milks were injected with $10 \mathrm{ml}$ of Corynebacterium cutis lysate three times, once every week (Lee et al., 1996). At the end of the administration, $85 \%$ decrease was observed in SCC. It was determined that this influence was started one week after the first administration and completed six weeks after the last administration. In the same study, it is reported that decrease in SCC and development of resistance against subclinical infections in the udder were observed one month after the administration of Corynebacterium cutis lysate to the cows which were identified with high SCC in their milk. In the present study, 88 udders having subclinical mastitis were injected once with the same immunostimulant. An increase in $\operatorname{IgG}$ count and no change in microbiological proliferation and SCC were observed in the examination of the same udder lobs after 15 days. Although the results of this study are in parallel with the above cited study there is still a difference in terms of SCC. The differences in drug injection numbers and herd health hygiene program are among the possible reasons for this situation.

In another study where the influence of Corynebacterium cutis lysate is investigated, treatment 
Table 1: Mean \pm SE CMT, SCC, IgG and microbiological analyses before and after the application of Corynebacterium cutis lysate.

\begin{tabular}{|c|c|c|}
\hline & Before & After \\
\hline CMT (positive) & $100 \%$ (n: 88$)$ & $63.63 \%(\mathrm{n}: 56)$ \\
\hline $\mathrm{SCC}($ cell $/ \mathrm{ml})$ & $897.47 \pm 109$ & $923.78 \pm 106$ \\
\hline $\operatorname{IgG}(\mathrm{mg} / \mathrm{ml})$ & $845.11 \pm 8.09$ & $887.27 \pm 9.07 *$ \\
\hline Microbiological analyses & $13.63 \%$ (n: 12$)$ & $22.73 \%(\mathrm{n}: 20)$ \\
\hline
\end{tabular}

and control groups were formed and followed for twelve weeks. At the end, it was figured out that drug administration did not change SCC and the quality of the milk (Pretorius, 2008). In the present study, evaluating the CMT, SCC, microbiological proliferation and IgG levels before and 15 days after the injection assessed the treatment efficiency of the same agent. In parallel to the above-cited study, SCC was not changed but in addition to that, a significant increase in $\mathrm{IgG}$ level was determined.

In this study, it was determined that Corynebacterium cutis lysate increases milk IgG levels. But, in a study where the effects of Corynebacterium cutis applied to pregnant sheep for immunostimulation purposes is investigated on postpartum total $\operatorname{IgG}$ levels and on lamb and sheep health, no impact were determined on the postpartum period in sheep and on the neonatal period in lambs (Yilmaz et al., 2011).

In conclusion, the obtained data showed that, although not statistically significant, microbiological growth rates and SCC were increased after Corynebacterium cutis lysate application in the cows with subclinical mastitis. However, it was observed that the milk IgG levels was increased significantly after the application. These results may indicate the use of Corynebacterium cutis lysate applications as a supportive treatment to enhance the resistance in cows against subclinical mastitis.

\section{Acknowledgments}

This study was supported by Firat University Scientific Research Projects Management Unit (FUBAP Project No: VF.11.09).

\section{References}

Al-Izzi SA, Maxie M, Savan M (1982) The pulmonary clearance of pasteurella haemolytica in calves given corynebacterium parvum and infected with parainfluenza-3 virus. Can J Comparat Med 46: 85-90.

Bastan A (2013) Udder Health and Problems in Cattle. Ankara: Kardelen Offset Print Co.

Carter GR (1984) Diagnostic Procedures in Veterinary Bacteriology \& Mycology. Springfield: CC Thomas.

Conesa C, Lavilla M, Sanchez L, Perez MD, Mata L, Razquin P, Calvo M (2005) Determination of IgG levels in bovine bulk milk samples from different regions of Spain. Eur Food Res Technol 59: 222225.

Gurbulak K, Canoglu E, Abay M, Atabay O, Bekyurek T (2009) Determination of Subclinical Mastitis in Dairy Cows by Different Methods. Kafkas Univ Vet Fak Derg 15: 765-770.

Gurbulak K, Kilicarslan MR (2004) The effect of Levamisole administration on the postpartum mastitis, metritis and foetal death in the pregnant cows. J Vet Fac Univ Istanbul 30: 35-46.

Koc A (2008) A Study of Somatic Cell Counts in the Milk of Holstein-Friesian Cows Managed in Mediterranean Climatic Conditions. Turk J Vet Anim Sci 32: 13-18.

Koneman EM, Allen SD, Janda WM (1997) Colour Atlas and Textbook of Diagnostic Microbiology. Philadelphia: J.B. Lippicott Comp.

Lee W.C, Kim T.J, Lee SM, Kim YC, Kwon YE, Cho JH, Woong J, Ann OJ (1996) An observative study on the application of Corynebacterium cutis lysate [Ultracorn] in decreasing of somatic cell count of the bulk milk from a herd of dairy cows for milk hygiene. Kor J Vet Pub Hlth 20: 349-352.

Mayr A (1978) Prämunität, Prämuniserung und paraspezifishe Wirkung von Schutzimpfungen. Münchener: Medicinische Wochenschrift.

Mayr A, Büttner M (1984) Neue erkenntnisse über die Grundlagen der Paramunität und Paramunisierung. Berl Munch Tierarztl 97: 429-435.

Pretorius C (2008) The Effect of Corynebacterium cutis Lysate to Control Somatic Cell Counts in Dairy Cows. University of the Free State, Bloemfontein, Doctoral thesis, South Africa.

Pyorala S (2003) Indicators of inflammation in the diagnosis of mastitis. Vet Res 34: 565-578.

Seker I, Risvanli A, Yuksel M, Saat N, Ozmen O (2009) Relationship between California Mastitis Test score and ultrasonographic teat measurements in dairy cows. Aust Vet J 87: 480-483.

Senturk S, Polat U, Kennerman E (2003) Determination of immune levels of calves of cows administered levamisole in dry period. J Vet Fac Univ Uludag 8: 711.

Shalaby MA, Saleh SM, El-Atrash S, Sami AM, ElSanousi AA, Saber MA, Reda MI (1992) Application of Corynebacterium cutis lysate as an immune stimulan in cattle. Mol Biotechnol 4: 147-150.

Smith KL (1996) Standards for somatic cells in milk: Physiological and regulatory. Mastitis Newsletter. Newsletters of the IDF 144: 7-9.

Yilmaz OT, Kasikci G, Gunduz MC (2011) Benefits of pregnant sheep immunostimulation with Corynebacterium cutis on post-partum and early newborn's life IgG levels, stillbirth rate and lamb's weight. Small Ruminant Res 97: 146-151. 